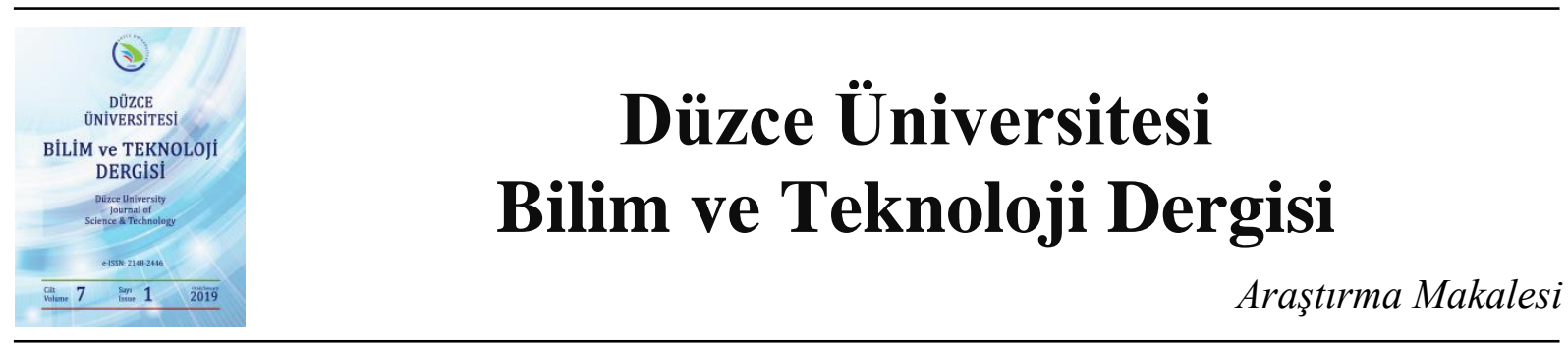

\section{Grafit Parçacık Takviyeli Nano Akışkan Kullanılarak AISI 316'nın Frezelenmesinde Yüzey Pürüzlülügü ve Kesme Sıcaklığının Optimizasyonu}

\author{
Çağrı Vakkas YILDIRIM ${ }^{\mathrm{a}, *}$ \\ ${ }^{a}$ Uçak Gövde Motor Bölümü, Havacıllk ve Uzay Bilimleri Fakültesi, Erciyes Üniversitesi, Kayseri, TÜRKIYYE \\ *Sorumlu yazarin e-posta adresi: cvyildirim@erciyes.edu.tr
}

\begin{abstract}
ÖZET
Minimum miktarda yağlama (MMY) sistemi, kullanılan kesme sıvısı miktarını önemli ölçüde azaltmaktadır. Böylece, konvansiyonel kesme sıvılarının getirdiği çevre, işçi sağlığı ve üretim maliyetlerinin artması gibi bazı dezavantajları ortadan kaldırmaktadır. Ancak, bu sistemde çok az miktarda kesme sıvısı kullanıldığı için soğutma kabiliyetinde azalmalar görülebilmektedir. Bu çalışmanın amacı, kesme sıvısının içerisine nano parçacık takviyesi yaparak MMY sisteminin soğutma kabiliyetini artırmaktır. Bu amaç doğrultusunda üç farklı soğutma/yağlama şartı (saf MMY, \%0,5 nano grafit içeren MMY ve \%1 nano grafit içeren MMY), üç farklı yağ debisi $(40,60$ ve $80 \mathrm{ml} / \mathrm{h})$ ve üç farklı püskürtme basıncı (4, 6 ve 8 bar) işleme parametresi olarak seçilmiștir. Değerlendirme ölçütü olarak yüzey pürüzlülüğü ve kesme sıcaklığı seçilmiștir. Zaman ve maliyetten tasarruf etme adına Taguchi L9 deney tasarımı tercih edilmiştir. Deney sonuçlarının değerlendirilmesinde S/N analizi dikkate alınmıştır. Faktörlerin etki seviyesini belirlemek adına varyans analizi (ANOVA) yapılmıştır. Son olarak da doğrulama deneyi yapılmış ve optimizasyonun geçerliliği test edilmiştir. Deney sonuçları analiz edildiğinde, yüzey pürüzlülüğü için optimum parametre grubu \%1 katkılı nano grafit takviyeli kesme yağı, $40 \mathrm{ml} /$ saat debi ve 8 bar püskürtme basıncı çıkarken kesme sıcaklığı adına \%1 katkılı nano grafit takviyeli kesme yağı, $80 \mathrm{ml} / \mathrm{saat}$ debi ve 8 bar püskürtme basıncı çıkmıştır.
\end{abstract}

Anahtar Kelimeler: AISI 316, Nano akışkan, MMY, Taguchi, nano grafit

\section{Optimization of Surface Roughness and Cutting Temperature in Milling of AISI 316 Using Graphite Particle Reinforced Nano Fluid}

\begin{abstract}
The Minimum Quantity Lubrication (MQL) system significantly reduces the amount of cutting fluid. Thus, it removes some of the disadvantages such as the environmental damage, workers health and increased production costs brought by conventional cutting fluids. However, in this system very little cooling is obtained because very little cutting fluid is used. The purpose of this work is to improve the cooling capability of the MQL system by making nanoparticle reinforcement into the cutting fluid. For this purpose, three different cooling/lubrication conditions, three different oil flow rates and three different injection pressures have been chosen as process parameters. Surface roughness and cutting temperature were chosen as the evaluation criteria. In order to save time and cost, Taguchi L9 experimental design was preferred. S/N analysis was considered for the evaluation of the test results. Analysis of variance (ANOVA) was performed to determine the level of
\end{abstract}


effect of the factors. Finally, the verification experiment was done, and the validity of the optimization was tested. Experimental results show that the optimum parameter group for surface roughness is $1 \%$ nano graphite reinforced cutting oil, $40 \mathrm{ml} / \mathrm{h}$ flow rate and 8 bar injection pressure while for cutting the temperature is $1 \%$ nano graphite reinforced cutting oil, $80 \mathrm{ml} /$ hour flow rate and 8 bar spray pressure.

Keywords: AISI 316, Nano fluid, MQL, Taguchi, nano graphen 